\title{
Put your lab in a different class
}

\author{
In many countries, students are turning away from the hard sciences. Can \\ initiatives that give young people hands-on experience of research help to \\ lure them back? Sally Goodman goes back to school.
}

\section{W} hen the US House of Representatives Committee on Government Reform met in February to hear evidence on anthrax research, its members were handed small plastic models of one of the anthrax toxins to help explain how drugs could be developed to treat infection with the bacterium. Little did they know that this physical representation of the protein had been designed by high-school students, using crystal-structure coordinates provided by the biologists giving evidence that day.

The project that yielded these models is just one of several schemes around the world that aim to involve teenagers in cutting-edge research. Their goal is to communicate the excitement felt by working scientists to school students who might otherwise perceive science as dry and dusty — and so to make young and enquiring minds consider taking a science degree, rather than opting for media studies or some other trendy subject. And if you've ever thought that you wanted to get involved in school science education but were unsure of what you could contribute, these schemes might provide some pointers.

The Team Anthrax project is a good place to start. Five months before the House committee hearing, in October 2001, mailed anthrax attacks were spreading terror across the United States. At that time, three students at Riverside University High School in Milwaukee, Wisconsin, were discussing biomolecular structures with their teacher, Jeff Anderson. Their goal was to turn such structures into three-dimensional models at the Milwaukee School of Engineering (MSOE). With anthrax dominating the news, its toxins were an obvious choice.

The MSOE's Center for BioMolecular Modeling (CBM) has the technology to turn structural data rapidly into plastic models. And Anderson had previously used the technology as part of a summer course for highschool science teachers. Back at his school, he realized that it could also provide the perfect means to get his high-school students excited about research.

Along with Tim Herman, the CBM's director, Anderson recruited a team of 17year-olds committed enough to spend their early mornings, evenings and weekends working on the project. "It was like finding pieces to a puzzle," says Justin Snowden, one of the three student members of Team Anthrax.

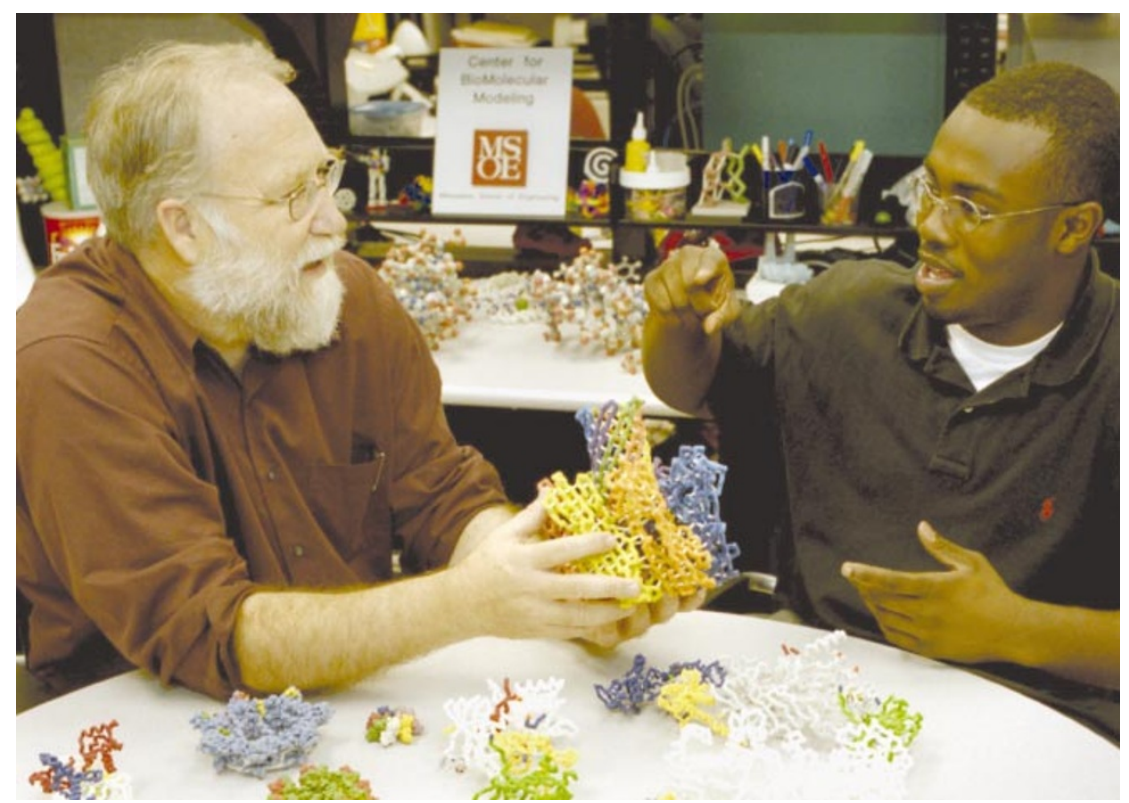

Building success: molecular modeller Tim Herman (left) gets creative with Justin Snowden, one of the high school students involved in Team Anthrax, a project to create models of the pathogen's toxins.

"We found out that three proteins were involved in anthrax pathogenesis and then tried to find out who was working on them."

They first approached Wei-Jen Tang, a biologist at the University of Chicago who released his data on the structure of one of the toxins - the anthrax oedema factor in advance of the publication of a paper describing the work (C. L. Drum etal. Nature 415, 396-402; 2002).

\section{Model students}

Using this privileged information, along with data made available by researchers working on the other anthrax toxins, the students first produced computer images using a molecular visualization program. This was then interpreted by the machines at the MSOE's Rapid Prototyping Center to produce three-dimensional colour models of the three anthrax toxins. "It was a completely new way of thinking for us, as we continually refined our designs," says Mia DeFino, another Team Anthrax member.

Tanglater visited the students. "It was a really rewarding exchange. I answered their questions on the protein's function and in return I got a wonderful model," says Tang, who says that he finds it useful as a communication tool when discussing his work with colleagues.

Tang also suggested ways in which the students could refine the model to better highlight the protein's function. "When Professor Tang looked at the model he said it was like holding his dream," says Snowden. "That was a really important moment for us."

The students also visited the laboratory of John Young at the University of WisconsinMadison, who has studied the binding between one of the anthrax toxins and a receptor found on the surface of mammalian cells. "I was very impressed that the students had come up with this model. It is an excellent tool for testing hypotheses," he says. So impressed was Young, in fact, that he later ordered 24 small copies of the model when he was called to give evidence to the Committee on Government Reform.

For the students, meeting the researchers provided a real confidence boost. "I was flattered that they talked to me as if I was a graduate student - even if I didn't always understand what they were saying," says DeFino.

Team Anthrax also roused interest among their high-school peers. "Sixty-five fellow students turned up on a Saturday morning to listen to them," says Anderson. "I don't think it was just the chips and soda that 


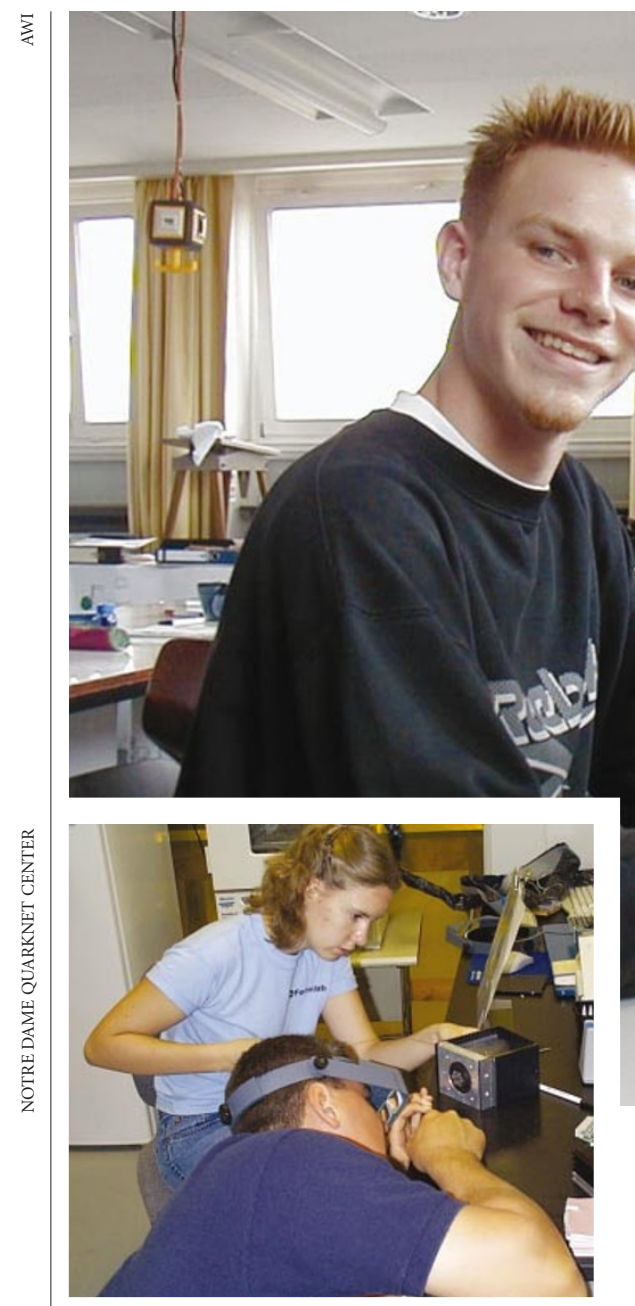

brought them in!" He adds that the experience has also expanded his outlook as a teacher. "This has really raised my expectations of my students," says Anderson, who is now working with another group on the toxins produced by Pseudomonas bacteria.

Herman now plans to extend the experience across the United States, and is setting up six local centres where teams of high-school children will create similar models of different molecular structures in conjunction with local labs. "This approach levels the playing field between researchers and students. The students can offer something of real value to the researcher," says Herman.

The same philosophy of creating a meaningful partnership between students, teachers and researchers lies behind another US project, this time in high-energy physics.

In December 1997, when the United States joined the project to build the Large Hadron Collider (LHC) at CERN, the European particle physics laboratory near Geneva, Neal Lane, then director of the National Science Foundation (NSF), said: "The LHC is unquestionably science at the frontier, and the potential educational benefit is just as exciting and unprecedented." His comments prompted the NSF and the US Department

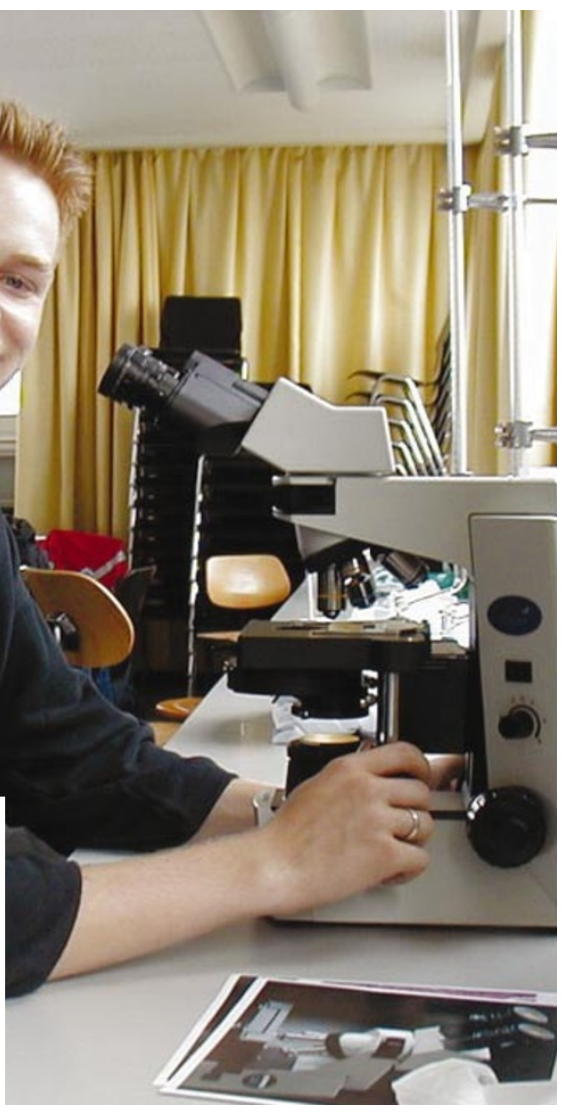

Matthias Eisel (above), one of 22 schoolchildren based at the Alfred Wegener Institute, gets to grips with ecology; left, Indiana students build components for high-energy physics studies.

of Energy to sponsor an effort to create an educational outreach programme.

The result was QuarkNet, which now comprises 44 centres across the United States where physics teachers meet regularly with highenergy physicists at local universities. Some of the teachers will previously have worked in the physicists' labs over the summer break - programming software, entering data or testing equipment. The following summer, these 'lead' teachers co-opt another dozen teachers and run a workshop based on their work. Back at school, the teachers can give lessons about contemporary projects instead of textbook examples of nineteenth-century physics.

\section{Labour of learning}

But Randy Ruchti of the University of Notre Dame in Indiana, a physicist working on the Compact Muon Solenoid (CMS) experiment for the LHC, wanted to take the experience further and get students actively engaged. With the teachers involved in the Notre Dame QuarkNet centre, Ruchti converted an old pizzeria on the university campus into a lab. For the past three summers it has provided space for some 45 high-school students, aged 16 and 17 , to come in and get paid for building components for Ruchti's experiments.
Last summer, the students built optical decoding units for use in the CMS. This involved threading optical fibres through holes in a box to ensure that the data would arrive at the right place when they were channelled through the other end. "This is very precise work, so it's good for young people with sharp eyesight," says Ruchti. Surprisingly, most of the students were not yet studying physics. "We get them green and unbiased, train them on the job and do the theory at lunchtime," says Ruchti.

"The students that came in to work with Randy saw that he had a real life and could converse normally," jokes Beth Beiersdorf, one of the teachers involved with Notre Dame's QuarkNet centre. She says that the experience was valuable both for academic high-fliers who might contemplate a career in research, and for those students with more practical skills. "They saw that there were also technicians handling the components as well."

Back at school, the effects are tangible. One teacher says that students who had worked with Ruchti started challenging him with probing questions. This shocked the other students until they saw that he responded positively, and then they joined in too.

Also through QuarkNet, physicist Yasar Onel of Iowa State University worked over the past summer with teacher Pete Bruecken and three of his students, testing photomultiplier tubes for the CMS. For Onel, the personal interactions were as important as the physics that the students learned. "They saw how we solved our problems," he says. "They became fully integrated and saw how important it was to work as a team."

The students produced a database of about 25 parameters to create a profile of the performance of 800 photomultiplier tubes which will be used over a 10 -year period. When the CMS begins to produce data in 2007, says Bruecken, "it is possible that these same highschool students could use the data collected to do their thesis work in graduate school".

Similar initiatives are springing up in Europe. Indeed, one German research institute has invited an entire class of local high-school students to work alongside its researchers. "When we went to propose the idea to the schools we were quite sure they would say it was impossible," says Rainer Paulenz, administrative manager of the Alfred Wegener Institute for Polar and Marine Research (AWI) in Bremerhaven. "So when they replied that it would be no problem, we were astonished."

After only eight months of planning, the first 22 students, aged 15-17, arrived at the centre in August (see Nature 418, 714; 2002). The students will spend two days a week at the centre over a three-year period and will be taught by their own teachers alongside AWI researchers.

In the first year, the students are working on special projects that link the school cur- 
riculum in chemistry, biology and mathematics to the work of the institute, for example by calculating nutrient budgets in the Wadden Sea ecosystem. AWI researchers explain the techniques at the beginning of the project and then will get involved at the end to help to interpret the results. An English teacher has also been pressed into service, helping the students to understand information from English-language Internet sites.

AWI researchers were asked to produce a list of what they could offer to the project, ranging from short seminars on their research to assistance in identifying plankton. Trips on one of the institute's research vessels or to one of its island field stations will also be arranged for small groups of students. And so that these lucky few can share their experience - and data - with the other students, laptops have been provided so that all participants have access to an intranet dedicated to the project.

Once students have learned the basic skills in their first year, they will become involved in ongoing research at the institute. Ulrich Bathmann, an oceanographer at the AWI who helped to set up the scheme, says that researchers are currently looking at areas where students can contribute. He says, for example, that they could work on projects to document genetic diversity in phytoplankton.

Although the main motivation is educational, Paulenz also sees it as a way to develop researchers' ability to communicate their own work. "It will be interesting to see if people find other secondary benefits," he says.

In Britain, meanwhile, some students working towards A-levels or equivalent qualifications - the exams on which university entrance depends - can get involved in research through a bursary scheme run by the Nuffield Foundation, a charity with broad interests that include science education.

Selected students can choose a project from a list circulated by regional coordinators after researchers in universities and industry have been canvassed for their offers. Each researcher then gets to choose the student that they will take on, usually after a telephone interview. The scheme, which has been running since 1995, finances some 600 bursaries per year, and is today also backed by government-funded research councils and other charities, such as the Wellcome Trust.

Students work on their projects for four to six weeks over the summer holidays. "We do most of our research over the summer, so the students come into a really active lab," says Dominic Campopiano, a biochemist at the University of Edinburgh. Last year his Nuffield student spent six weeks in the lab and was able to clone a gene and overexpress a protein from Aquifex aeolicus, a bacterium that lives in scalding waters near volcanic vents on the sea floor. This student is the second author on a paper that Campopiano has recently submitted for publication. "He picked up the techniques quickly," says Campopiano.

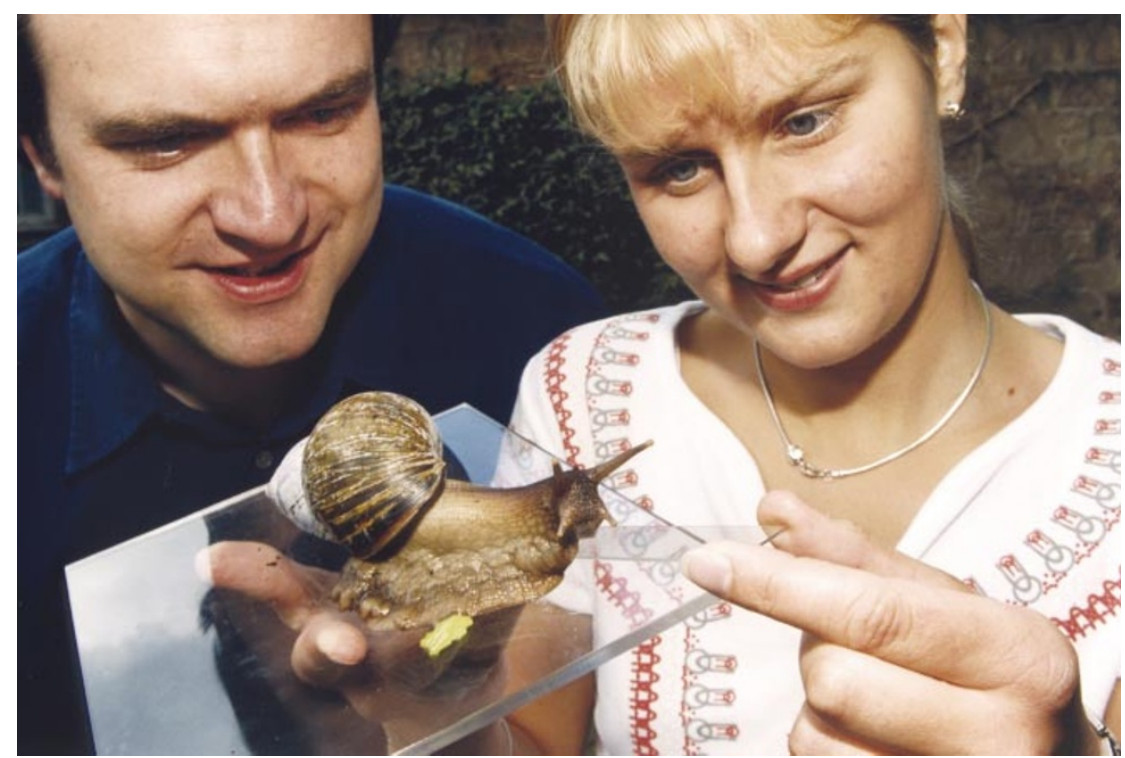

Work done on snails by Mairi Struthers and her mentor Chris Viney could have medical applications.

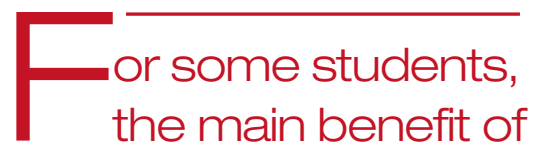

animal-welfare research, for example, instead. It really took the pressure off," she says.

The Nuffield scheme seems so successful in generating enthusiasm that some researchers fear that its participants may be brought down to Earth with a bump when faced with the realities of undergraduate education. "You have to explain that what they are doing is cutting-edge research and they will have to go way back to the start and learn the fundamentals when they are undergraduates," says Campopiano.

Nevertheless, the students involved in these schemes are, most observers say, a fortunate few. And the researchers who have worked with them also consider themselves lucky. "It was incredibly exhilarating to work with such motivated and enthusiastic young people," says Ruth Robinson, a sedimentologist at the University of St Andrews, UK, who has had two Nuffield students in her lab.

The real test of these programmes will be whether they can be expanded to reverse the current trend in many industrialized nations towards declining enrolment in university science courses. Who knows, perhaps the House of Representatives Committee on Government Reform might one day include a scientifically enlightened member with a distant memory of a summer spent getting to grips with biomolecular structures.

Sally Goodman was until recently Nature's French correspondent.

Team Anthrax

www.rpc.msoe.edu/sepa/teamanthrax.htm QuarkNet

quarknet.fnal.gov

Alfred Wegener Institute School Project

www.awi-bremerhaven.de/AWI/Presse/PM/ 020916Schulprojekt-e.html

Nuffield Science Bursaries for Schools and Colleges

- www.nuffieldfoundation.org/grants/scibsc/

overview.asp 